\title{
ATTRACTION AREA DIVISION AND FREIGHT FLOW ORGANIZATION OPTIMIZATION OF INLAND RAILWAY CONTAINER TERMINAL
}

\author{
Chuanzhong YIN 1 , Yu $\mathrm{LU}^{2 *}$, Ziru WANG ${ }^{3}$, Yang $\mathrm{YAN}^{4}$, Xinpei XU ${ }^{5}$ \\ ${ }^{1}$ College of Transport and Communications, Shanghai Maritime University, Shanghai, China \\ ${ }^{2}$ MOE Key Laboratory of Road and Traffic Engineering, Tongji University, Shanghai, China \\ ${ }^{3}$ ZhongYu Design Co. Ltd., Hainan, Haikou, China \\ ${ }^{4}$ Hangzhou Hikvision Digital Technology Co. Ltd., Shanghai Branch, Shanghai, China \\ ${ }^{5}$ School of Transportation and Logistics, Southwest Jiaotong University, Chengdu Sichuan, China
}

Submitted 16 June 2019; resubmitted 22 October 2019, 2 February 2020; accepted 4 May 2020;

first published online 18 March 2021

\begin{abstract}
The attraction area division is the foundation of distribution and organization of freight flow among railway stations. The development of railway container terminal, large railway freight distribution center, is closely related to logistics planning and economy development of local city. In this study, we divide freight flow attraction area of inland railway container terminal by using gravity model, break-point model and weighted-Voronoi-diagram with SPSS and ArcGIS. And then under the target of minimal cost and time window limitations, we develop 0-1 integer programming model for freight flow organization optimization between inland terminal and its attraction area. Finally, this paper takes railway container terminal in Harbin as an example to test model feasibility under different speeds from different transportation modes. The results show that it is necessary to divide attraction area when choosing reasonable transportation mode from feeder nodes to railway container terminal. The improvement of feeder transportation speed is an effective method to improve freight volume, increase railway revenue and realize sustainable development of China Railway (CR) Express.
\end{abstract}

Keywords: freight transportation, China Railway Express, gravity model, break-point model, 0-1 integer programming.

\section{Introduction}

The China Railway (CR) Express is a fast-freight group of trains that is suitable for container transportation between China and Europe. Among the cities where CR Express operates, inland cities with rapid development take up the majority. Moreover, CR Express builds up some new forms of businesses and pushes inland cities to the forefront of opening-up and cooperation with outside world.

With the development of CR Express and gradual improvement of inland transportation network, local governments develop different freight subsidy standards for CR Express to attract more businesses. Consignors are willing to invest a lot of transportation resources to get more freight subsidy, by even choosing farther operation railway stations of CR Express to transport goods (Table A1 in the Appendix). However, this brings about chaotic transportation rules, leading to disordered competition in the CR Express freight organization, and it fails to take the most advantage of various freight modes. And it also leads to serious waste of transportation resources to a large extent and restricts the sustainable development of CR Express. The key problem in this paper is the division of attraction region. On the basis of the division of attraction area, the further research on the optimization of freight flow organization will give the decision makers a clearer idea of decision-making.

Our contributions are as follows. In this paper, we divide freight flow attraction area of inland railway container terminal by using gravity model, break-point model and weighted-Voronoi-diagram with SPSS (https://www. ibm.com/analytics/spss-statistics-software) and ArcGIS (https://www.arcgis.com). Then we establish a $0-1$ integer programming model of freight flow organization optimization between inland terminal and its attraction area, with minimal transportation cost and time window

*Corresponding author. E-mail: 18817775720@163.com 
limitations. Moreover, we take railway container terminal in Harbin as an example to test the model feasibility under different speeds from different transportation modes. Therefore, in this research, by gravity model, break-point model and weighted-Voronoi-diagram, we make comprehensive analysis and establish freight organization optimization model with time window constraint to solve this problem. The research results are not only applicable to the CR Express, but also can provide a guidance for the general block train operation.

This study is organized as follows. Section 1 describes the related literature review of attraction area division of terminals, transportation mode selection and freight flow organization. Section 2 makes a comprehensive analysis based on spatial interactions. Section 3 illustrates a freight organization optimization model from attraction area to the terminal of CR Express. In Section 4, the model feasibility under different speeds from different transportation is tested through a case study in Harbin. The final section presents the conclusion of this study.

\section{Literature review}

The research is embodied in three aspects: attraction area division of terminals, transportation mode selection and freight flow organization.

In the aspect of the research on attraction area division of terminals, it can be divided into the attraction area of passenger and freight transportation station. In the attraction area division for passenger transportation station, passenger walking distance, time, behaviour differences and passenger transport operators are considered to design model (O’Sullivan, Morrall 1996; Kim et al. 2010; ElGeneidy et al. 2014). The algorithm usually has the shortest distance algorithm, minimum real-time algorithm and the improved p-median algorithm (Wang, Shi 2017). In addition, Yu et al. (2014) classify and quantify a series of urban agglomerations based on object automatic detection and night-time satellite map. In the attraction area division for freight transportation station, Galvão et al. (2006) use multiplication weighted-Voronoi-diagram to solve the problem of attraction area in the logistics progress. Factors such as land use, transportation network and business size are usually taken into account in the model establishment (Lawson et al. 2012; Sánchez-Díaz et al. 2016). The methods adopted in the analysis include spatial econometric techniques, ambivalence model, gravitational model, weighted-Voronoi-diagram and discrete generation algorithm (Abellanas et al. 2003; Wei et al. 2008).

In the aspect of transportation mode selection, as different transportation modes have different unit costs, cost minimization is usually one of the objectives of optimization (Banomyong, Beresford 2001). In addition, the optimization objects of the model include time, risk, carbon emission and environmental protection (Choong et al. 2002; Verma, Verter 2010; Verma et al. 2012; Demir et al. 2016; Jiang, Zhang 2016; Seo et al. 2017; Xia et al. 2019). In terms of model establishment, the models are mainly in the form of integer programming, multi-model decisionmaking and mixed integer programming (Choong et al. 2002; Qu et al. 2008; Bierwirth et al. 2012; Demir et al. 2016). In algorithm design, adaptive neural network system, iterative decomposition method, tabu search algorithm and other heuristic algorithms are used to solve the problem (Qu et al. 2008; Verma, Verter 2010; Verma et al. 2012). Besides, Jiang et al. (2012) use carbon dioxide emission calculation model published by Intergovernmental Panel on Climate Change (IPCC) to measure carbon dioxide emissions. They provide data support and practical guidance for the low-carbon development of multimodal transport in building low-carbon ports.

The research on freight transportation organization mainly includes optimization of dispatching routes, freight flow assignment and transportation network. As for dispatching routes optimization, the optimization goal is generally to minimize some factors such as transportation cost and transportation time (Chang 2008; Yang et al. 2011). Mixed integer programming, shortest path model, integer programming forms are mainly adopted in model establishment, and the algorithms adopted mainly include time series algorithm, dynamic programming algorithm and heuristic algorithm (Lozano, Storchi 2001; Zografos, Androutsopoulos 2008; Cho et al. 2012). In terms of freight flow assignment optimization, the main research is to optimize the objective of the distribution of goods in the transport network (Corry, Kozan 2006; Kalinina et al. 2013; Bhattacharya et al. 2014; Hübner, Ostermeier 2018). Transportation cost, time, carbon emission and other factors are generally considered as optimization targets. Dynamic distribution model, mixed integer programming model, mixed linear programming model are mainly used in the model establishment (Corry, Kozan 2006; Bhattacharya et al. 2014; Borndörfer et al. 2016). In algorithm design, dynamic programming algorithm, heuristic algorithm and hybrid heuristic algorithm are usually used to solve the model (Hao, Yue 2016). Furthermore, Talley and Ng (2018) build a behavioural model based on non-cooperative game theory, and study the influence of decision-making behaviours of major players on hinterland supply chain, namely ports, shippers and multimodal transport operators, on the choice of hinterland transport chain. In terms of transportation network optimization, the optimization targets are usually the efficiency, time and benefit of the transportation network (Butko et al. 2019; Feng et al. 2019). In general, it adopts the form of mixed integer programming, such as bi-objective and multi-objective optimization, and uses genetic algorithm and other heuristic algorithms to solve the problem (Wei, Dong 2019). In addition, Yao et al. (2002) establish an improved linear optimization model for multi-objective optimization considering both bidirection and empty-loaded train certain transportation requirement.

Attraction area division research mainly considered the influence of transport time, distance and cost, but researchers seldom consider influence that interaction between the city where freight flows are and the neigh- 
bouring city has on attraction area division. In terms of transportation mode selection, analysis is mainly carried out with the lowest transportation cost, the shortest transportation time, and the best environmental protection scheme, without taking into account the influence of hinterland freight flow organization on transportation mode selection.

At present, research on flow organization optimization mainly focuses on three aspects: dispatching routes, freight flow assignment and transportation network. However, research on freight flow organizational optimization in inland areas and freight flow from multiple origins to the same destination is relatively insufficient. On the basis of literature review, we first adopt comprehensive analysis based on spatial interaction, which means, gravity model, break-point model and weighted-Voronoi-diagram are applied, also SPSS and ArcGIS are combined to divide attraction area of terminal. Then, based on attraction area, we construct a $0-1$ integer programming model for freight organization optimization on CR Express. Finally, we verify feasibility of research method by taking Harbin Railway Container Center Station (HRCCS) as an example.

The innovation of this study lies in comprehensive analysis based on spatial interaction, which combines gravity model, break-point model and weighted-Voronoidiagram. Most of the traditional methods only consider distance or cost. The method of attraction area division proposed in this paper not only considers the distance between two cities, but also the comprehensive strength of the carrier city and the strength of economic connection with other cities. The method in this paper is more comprehensive than traditional method. In addition, we analyse the attraction area of inland railway container terminal and establish freight organization optimization model with time window constraint by combining with attraction area division. Thus, we obtain optimal freight organization mode in attraction area of CR Express, and verify the method feasibility through practical examples in the end.

\section{Spatial interactions comprehensive analysis}

Based on economic geography theory, this method considers that development of traffic lanes, stations or ports, as a part of the support for carrier city, cannot be separated. Attraction area of traffic lane, station or port is influenced by economic and social development of the carrier city. To reflect the interaction among a carrier city and its surrounding cities, commonly used models such as gravity model and break-point model are able to make sense. In gravity model, distance attenuation function is mainly used to reflect the attenuation law of gravity with increasing distance between two cities (Boukebbab 2015). While key idea of break-point model is that attraction area of a city is determined by city scale and distance between neighbouring cities. Moreover, the equilibrium point between two neighbouring cities is called the breaking point (Bowen 2012).
As there are many indexes in evaluation system, the comprehensive power of each city can be calculated with the concept of dimension reduction in principal component analysis (Moore 1981). We put its results into the corresponding formulas of gravity model and break-point model to obtain attraction area of carrier city.

\subsection{Gravity model}

Based on the universal gravitation in Newtonian mechanics, gravity model mainly uses the distance attenuation function to reflect attenuation law of gravity with increasing distance between two cities. What's more, one of characteristics about gravity model is that if we keep its basic form unchanged and reasonably define the parameters, it can be applied to other researches (Lu, Huo 2013). The formula of gravity model is usually defined as follows:

$$
T_{i k}=K \cdot \frac{Y_{i} \cdot Y_{k}}{d_{i k}^{2}},
$$

where: $T_{i k}$ is the intensity of gravity between two cities; $K$ is constant (gravitational coefficient); $Y_{i}, Y_{k}$ are endogenous variables; $d_{i k}$ means distance between city $i$ and city $k$.

We take urban comprehensive power to modify gravity model. As following calculation has faction reduction, we set $K$ to 1 , and consider the endogenous variables as comprehensive power of cities. In terms of the gravity model definition, economic connection degree between carrier city and its surrounding city is directly proportional to its comprehensive power and inversely proportional to its distance. The formulas are as follows:

$$
\begin{aligned}
& F_{i k}=\frac{\sqrt{S_{i} \cdot S_{k}}}{D_{i k}^{2}} ; \\
& F_{i}=\sum F_{i k},
\end{aligned}
$$

where: $F_{i k}$ refers to economic connection degree between city $i$ and city $k ; S_{i}, S_{k}$ are comprehensive power of city $i$ and city $k ; D_{i k}$ means the shortest distance between city $i$ and city $k ; F_{i}$ means the aggregate economic connection degree among city $i$ and all other cities in the region, namely the total external economic connection degree of city $i$.

The greater economic connection degree between one city and carrier city in the region is, the closer economic connections the city and carrier city have, namely the more attractive it is. In this study, based on gravity model calculation, we obtain economic connection degree between the carrier city and each city in the region, and then rank them in descending order. As usual, in this study, cities whose economic connection degree has reached $85 \%$ of total external economic connection degree, that is, cities whose membership degree has reached $85 \%$, are included in attraction areas of carrier city. We can see calculation formula as follows:

$$
\beta_{i k}=\frac{F_{i k}}{F_{i}},
$$

where: $\beta_{i k}$ refers to proportion of economic connection 
degree in the total external economic connection degree, namely the membership degree on economy connection; $F_{i k}$ refers to economic connection degree between city $i$ and city $k ; F_{i}$ means total external economic connection degree of city $i$.

\subsection{Break-point model}

In the case of multiple attraction points, division based on gravity model does not consider influence of multilateral resistance, thus it cannot accurately describe attraction area boundary of multiple attraction points. However, break-point model can exactly solve this problem. The formula (Long et al. 2011) of break-point model is as follows:

$$
d_{i}=\frac{D_{i k}}{1+\sqrt{\frac{P_{k}}{P_{i}}}},
$$

where: $d_{i}$, is the distance from break-point to city $i ; D_{i k}$ means the shortest distance between city $i$ and city $k ; P_{i}$, $P_{k}$ are respectively the population scale of city $i$ and city $k$.

However, in practical application, break-point model still has the following shortcomings:

"») it is not comprehensive to consider population scale as the attraction of a city in the formula, so population scale is replaced by comprehensive power in this paper;

"»» we only get one point between two cities through the formula, but in fact, it is not very possible to get the boundary of attraction area between two cities by one point arbitrarily.

For above deficiencies, we can modify it based on the assumption that attraction area boundary between two cities is an arc from weighted-Voronoi-diagram.

Definition of weighted-Voronoi-diagram is as follows.

Voronoi has the function of spatial partition (Figure 1). The distance from any point in Voronoi grid to the center of the grid is less than that from other grid centers. Set $X=\left(X_{1}, X_{2}, \ldots, X_{n}\right), 3 \leq n \leq \infty$ to a control point aggregate in 2D Euclidean space. Set $w_{i}(i=1,2, \ldots, n)$ to $n$ certain positive real numbers, and $x$ to a random point in the area. The formula is as follows:

$$
\begin{aligned}
& V_{n}\left(X_{i}, w_{i}\right)=\underset{j \neq i}{\cap}\left(x \mid \frac{d\left(x, X_{i}\right)}{w_{i}} \leq \frac{d\left(x, X_{j}\right)}{w_{j}}\right), \\
& i=1,2,3, \ldots, n .
\end{aligned}
$$

Firstly, we divide the plane into $n$ parts. Then the plane division that is determined by $V_{n}\left(x_{i}, w_{i}\right)(i=1,2, \ldots, n)$ is weighted-Voronoi-diagram, where $w_{i}$ is called the weight of $X_{i}$. Unlike old Voronoi-diagrams, weighted-Voronoidiagram breaks the rule that Voronoi-diagrams are homogeneous, and it is suitable for spatial segmentation in cases where weights of each site are obviously different. We can assume that all points in the region defined by weightedVoronoi-diagram are mostly affected by the site in that a)

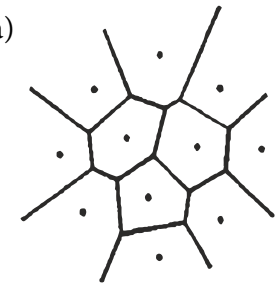

b)

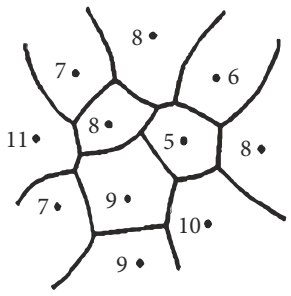

Figure 1. Diagrams: a - regular-Voronoi-diagram; $\mathrm{b}$ - weighted-Voronoi-diagram

region. In this study, we take the central city in one region as a site, and the other cities within the region are affected more by it than the central city in the adjacent region.

The following inferences can be obtained by analysing the break-point formula: We take two cities as the sites, its attraction weigh is proportional to square root of the comprehensive external economic connection degree of two neighbouring cities, which is shown in the following formula:

$$
\frac{w_{i}}{w_{k}}=\sqrt{\frac{F_{i}}{F_{k}}} .
$$

Based on Equation (7), we can get Voronoi-diagrams weighted by square root of comprehensive external economic connection degree of each city. The formula combining break-point model with weighted-Voronoi-diagram is shown below:

$$
\begin{aligned}
& V\left(X_{i}, \sqrt{F_{i}}\right)=\left(x \in V\left(X_{i}, \sqrt{F_{i}}\right) \mid \frac{d\left(x, X_{i}\right)}{\sqrt{F_{i}}} \leq \frac{d\left(x, X_{j}\right)}{\sqrt{F_{j}}}\right), \\
& j=1,2,3, \ldots, n ; j \neq i .
\end{aligned}
$$

To visually represent attraction area, which is formed by break-point model and weighted-Voronoi-diagram, we use ArcGIS to work on it. The specific steps are as follows:

"» Step 1: create a constant grid after loading the data, and then set the constant to 1 and pixel to 3000 ; after creating the grids, turn them into points;

"1) Step 2: create a distance diagram to calculate the distance from the grid point to central city; next add the field "time" to attribute table to weigh every distance; that is, the weight of central city is regarded as speed; and the "time" equals to the distance divided by city attraction weight;

"» Step 3: connect attribute table of central city with comprehensive power table of central city by Microsoft Excel; then connect the two attribute tables of distance and central city, and calculate values of field "time";

"» Step 4: to obtain the shortest time from each grid point to every central city, summarize the distance table and get statistical table of minimum distance; next connect it with attribute table of central city;

"» Step 5: turn the points to grid, then to the plane, and turn elements to the lines; finally, we can get the weighted-Voronoi-diagram through modification. 


\section{Freight organization optimization model}

In the above, we have divided final attraction area by using gravity model, break-point model and weighted-Voronoidiagram, with SPSS and ArcGIS. The following part builds up the freight organization optimization model from attraction area to the terminal of CR Express.

\subsection{Problem description}

In the freight organization optimization, problem of the freight routine and transport mode selection can be described as follows: suppose that a certain amount of freights are transported from the origin to the destination, and there are two modes of transportation: one is that freights are transported directly from original station to the destination without transfer, the other is that freights are firstly transported to the transfer station, changed transport mode, and then to the destination. Due to the different cost and time of each transport modes, when transport mode is converted at a certain node, transit time and fee happen. Therefore, we need to consider above factors and the timeliness, choosing the optimal routine and transport mode to minimize total cost in the whole transportation process.

\subsection{Assumptions}

Assumptions are:

"» during the transportation process, freight cannot be separated, that is, only one mode of transportation can be selected between two adjacent stations;

"») the freight can only be transferred at the station not more than once;

"» the yard, facilities and other conditions of all stations meet the transfer operation requirement;

"» the time limit of transportation is known.

\subsection{Parameter definition}

$N$ - set of station, $i, j, s \in N$;

$Q$ - set of transportation mode, $p, q \in Q$;

$m_{i, j}$ - the amount of freight transported from point $i$ to point $j[\mathrm{t}]$;

$m_{i j}^{p_{j}}$ - transportation capacity of mode $p$ adopted between point $i$ and point $j[\mathrm{t}]$;

$m_{s}^{p q}$ - transfer capacity of transfer station $s$ where transportation mode changes from $p$ to $q[\mathrm{t}]$;

$c_{i j}^{p}$ - unit mileage freight rate between point $i$ and point $j$ with transportation mode $p, p \in Q$ [yuan/t.km];

$c_{s}^{p q}$ - unit transfer cost of station $s$ where transportation mode changes from $p$ to $q, p, q \in Q$ [yuan/t];

$l p_{i j}$ - distance between point $i$ and point $j$ with transportation mode $p[\mathrm{~km}]$;

$v_{i j}^{p_{j}}$ - speed between point $i$ and point $j$ with transportation mode $p[\mathrm{~km} / \mathrm{h}]$;

$t_{s}^{p q}$ - transfer time at station $s$ where transportation mode changes from $p$ to $q[\mathrm{~h}]$;

$T_{\min }, T_{\max }-$ lower limit and upper limit of time window.
Decision variables:

$x_{i, j}^{p}= \begin{cases}1, & \text { using transportation } \\ \text { mode } p \text { from point } i \text { to point } j ; & \text { otherwise; }\end{cases}$
$y_{i, j}^{p q}= \begin{cases}1, & \text { changing transportation mode } p \text { to } q \\ \text { during the transportation from } & \text { point } i \text { to point } j ; \\ 0, & \text { otherwise. }\end{cases}$

3.4. Modelling

$\min Z=\sum_{i \in N} \sum_{j \in N} \sum_{p \in Q} m_{i, j} \cdot l_{i, j}^{p} \cdot c_{i, j}^{p} \cdot x_{i, j}^{p}+$
$\sum_{i \in N} \sum_{j \in N} m_{i, j} \cdot c_{s}^{p q} \cdot y_{i, j}^{p q}$

subject to:

$\sum_{p \in Q} x_{i, j}^{p}=1, i, j \in N$;

$\sum_{p \in Q} \sum_{q \in Q} y_{i, j}^{p q} \leq 1, i, j \in N$;

$x_{i, j}^{p} \cdot m \leq m_{i, j}^{p}, i, j \in N, p \in Q ;$

$\sum_{j} y_{i, j}^{p q} \cdot m_{i, j} \leq m_{s}^{p q}, i, j \in N$;

$T_{\min } \leq \sum_{p} \frac{l_{i, j}^{p}}{v_{i, j}^{p}} \cdot x_{i, j}^{p}+t_{s}^{p q} \cdot y_{i, j}^{p q} \leq T_{\max }, \forall i, j ;$

$x_{i, j}^{p} \in[0,1], y_{i, j}^{p q} \in[0,1], i, j \in N, p \in Q$.

Equation (9) is the objective function, which aims to minimize total transportation and transfer cost from origin to destination. Equation (10) guarantees the integrity of freight. Equation (11) limits that freight in any station does not transfer more than once. Equations (12) and (13) respectively ensure transportation capacity between point $i$ and point $j$ and transfer operating capacity of transfer station $s$. Equation (14) restricts arrival time within the time limit. Equation (15) determines the value of decision variables, that is, $x_{i, j}^{p}$ means freights are transported from city $i$ to city $j$ by transportation mode $p, y_{i, j}^{p q}$ means freights are transferred or not during the transport process from city $i$ to city $j$, subject to 0 or 1 .

\section{Case study}

HRCCS is one of key cooperation projects between China Railway Corporation and Heilongjiang Province. Now it has been listed as a major infrastructure construction project of Heilongjiang Province party committee and government to construct "China - Mongolia - Russia" economic corridor and Heilongjiang land and sea silk road economic belt. After HRCCS being put into operation, Harbin will be regarded as the core region to form a 
modern international logistics center oriented to Russia, radiating to east Europe and northeast Asia, which is of great significance to promote development of CR Express.

\subsection{Evaluation system establishment of HRCCS}

Evaluation system of comprehensive power has 11 indicators, including regional Gross Domestic Product (GDP), fixed asset investment, retail sales of consumer goods, local public financial revenue, total industrial output value, proportion of non-agricultural industries to GDP, proportion of non-agricultural industry employees, population size, the scale of built-up areas, freight volume, and posts and telecommunications services. According to these indicators, using principal component analysis, with data of 38 cities in northeast economic zone in China Statistical Yearbook 2016 (CSP 2016), we can obtain the eigenvalues, variance contribution rates, and cumulative contribution rates of correlation matrix through SPSS, as shown in the Table 1.

11 principal components refer to 11 variables. Extraction of principal components is based on eigenvalue and cumulative contribution rate of each indicator. Larger the eigenvalue is, larger the contribution rate will be, indicating that the factor is more capable to represent the comprehensive power of city. Only if the eigenvalue is greater than 1 and cumulative contribution rate is greater than $85 \%$, can the factor be selected as principal factor. As is shown in the Table 1, cumulative contribution rate of the first two principal components is $87.098 \%$, and their eigenvalues are both greater than 1 , while percentage of the following nine factors is relatively small. It is indicated that information contained in the first two factors can reflect most information of 11 parameters in the original data. Therefore, the first two factors are denoted as $R_{1}$ and $R_{2}$, to replace the original 11 indicators. Their corresponding eigenvalues are denoted as $\lambda_{1}$ and $\lambda_{2}, \psi_{1}$ and $\psi_{2}$ denote as the variance contribution rates.

We get the principal factor loading matrix via SPSS, and coefficients through Equation (16). The result is shown in Table 2 .
Table 1. Eigenvalue and principal component contribution rate

\begin{tabular}{|l|c|c|c|}
\hline \multicolumn{1}{|c|}{$\begin{array}{c}\text { Principal } \\
\text { component }\end{array}$} & Eigenvalue & $\begin{array}{c}\text { Variance } \\
\text { contribution } \\
{[\%]}\end{array}$ & $\begin{array}{c}\text { Cumulate } \\
\text { contribution } \\
{[\%]}\end{array}$ \\
\hline 1 - regional GDP & 8.269 & 75.169 & 75.169 \\
\hline $\begin{array}{l}\text { 2- fixed asset } \\
\text { investment }\end{array}$ & 1.312 & 11.929 & 87.098 \\
\hline $\begin{array}{l}3-\text { retail sales of } \\
\text { consumer goods }\end{array}$ & 0.506 & 4.604 & 91.702 \\
\hline $\begin{array}{l}4-\text { local public } \\
\text { financial revenue }\end{array}$ & 0.304 & 2.759 & 94.462 \\
\hline $\begin{array}{l}5-\text { total industrial } \\
\text { output value }\end{array}$ & 0.241 & 2.188 & 96.649 \\
\hline $\begin{array}{l}6-\text { proportion of } \\
\text { non-agricultural } \\
\text { industries to GDP }\end{array}$ & 0.170 & 1.543 & 98.192 \\
\hline $\begin{array}{l}7 \text { - proportion of } \\
\text { non-agricultural } \\
\text { industry employees }\end{array}$ & 0.098 & 0.889 & 99.081 \\
\hline $8-$ population size & 0.050 & 0.453 & 99.534 \\
\hline $\begin{array}{l}9-\text { the scale of } \\
\text { built-up areas }\end{array}$ & 0.025 & 0.226 & 99.760 \\
\hline 10 - freight volume & 0.021 & 0.189 & 99.949 \\
\hline $\begin{array}{l}11-\text { posts and } \\
\text { telecommunications } \\
\text { services }\end{array}$ & 0.006 & 0.051 & 100.000 \\
\hline
\end{tabular}

$$
R_{k}=\frac{A_{k}}{\sqrt{\lambda_{k}}}
$$

where: $R_{k}$ is the coefficient of principal component; $A_{k}$ is the principal factor load; $\lambda_{k}$ is the eigenvalue of principal factor, $k=1,2$.

Then score of each principal component and original score of comprehensive power can be calculated by Equations (17) and (18):

$$
U_{i k}=H_{i} \cdot R_{k},
$$

where: $H_{i}$ is the standard score matrix of original variables in city $i$ after standardization via SPSS (the number

Table 2. The coefficient and load of principal factor

\begin{tabular}{|c|c|c|c|c|}
\hline $\begin{array}{c}\text { Original } \\
\text { parameter }\end{array}$ & $\begin{array}{c}\text { The first principal } \\
\text { factor loading } A_{1}\end{array}$ & $\begin{array}{c}\text { The second principal } \\
\text { factor loading } A_{2}\end{array}$ & $\begin{array}{c}\text { Coefficient of the first } \\
\text { principal factor } R_{1}\end{array}$ & $\begin{array}{c}\text { Coefficient of the second } \\
\text { principal factor } R_{2}\end{array}$ \\
\hline$\partial_{1}$ & 0.984 & -0.035 & 0.342 & -0.031 \\
\hline$\partial_{2}$ & 0.973 & -0.061 & 0.338 & -0.053 \\
\hline$\partial_{3}$ & 0.913 & -0.090 & 0.318 & -0.079 \\
\hline$\partial_{4}$ & 0.981 & -0.075 & 0.341 & -0.065 \\
\hline$\partial_{5}$ & 0.882 & -0.011 & 0.307 & -0.010 \\
\hline$\partial_{6}$ & 0.496 & 0.743 & 0.172 & 0.649 \\
\hline$\partial_{7}$ & 0.359 & 0.832 & 0.125 & 0.726 \\
\hline$\partial_{8}$ & 0.849 & -0.110 & 0.295 & -0.096 \\
\hline$\partial_{9}$ & 0.936 & -0.089 & 0.325 & -0.078 \\
\hline$\partial_{10}$ & 0.929 & -0.095 & 0.323 & -0.083 \\
\hline$\partial_{11}$ & 0.972 & -0.147 & 0.338 & -0.128 \\
\hline
\end{tabular}


of original variables is $j) ; H_{i}=\left(h_{i 1}, h_{i 2}, \ldots, h_{i j}\right), i=1,2, \ldots$, $38, j=1,2, \ldots, 11 ; R_{k}$ is the coefficient of the $k$ th principal component, $R_{k}=\left(r_{k 1}, r_{k 2}, \ldots, r_{k j}\right)^{T}, k=1,2, j=1,2, \ldots, 11$; $U_{i k}$ is the score of the $k$ th principal component in city $i$;

$$
U_{i}=\frac{\sum \psi_{k} \cdot U_{i k}}{\sum \psi_{k}},
$$

where: $U_{i}$ is the original score of comprehensive power in city $i ; \psi_{k}$ is the variance contribution rates; $i=1,2, \ldots$, $38, k=1,2$.

Since there are negative numbers in comprehensive power scores, it is unreasonable to directly put them into the formula of break-point model, which has the square root operation. Therefore, we need to use the minimummaximization norm method to transform the city comprehensive power original scores:

$$
\begin{aligned}
& v^{\prime}=\frac{v-\min A}{\max A-\min A} \times \\
& \left(n e w \_m a x A-n e w \_\min A\right)+n e w \_m i n A,
\end{aligned}
$$

where: $v^{\prime}$ is the data after standardization; $v$ is the original data; $\max A$ and $\min A$ are respectively the maximum and minimum value of original data; new_max $A$ and $n e w \_$min $A$ are respectively the maximum and minimum value of the standardized data, which restrict comprehensive power scores of each city to the range $[1,10]$.

\subsection{Attraction area division of HRCCS}

\subsubsection{Attraction area division}

Table 3 shows the comprehensive power and its ranking of cities in the economic zone of northeast China. Among them, central cities in the region are selected with the score greater than 0 . Therefore, central cities are Shenyang, Dalian, Changchun, Harbin, Jilin, Anshan, Daqing and Chifeng. By using ArcGIS, we can see the attraction area of Harbin in the Figure 2.

As we can see in the Figure 2, cities within the attraction area of Harbin include Heihe, Yichun, Hegang, Jiamusi, Shuangyashan, Qitaihe, Jixi, Mudanjiang, northwest of Hailar (Oroqen Autonomous Banner, Genhe, Ergun, Manzhouli, Prairie Chenbarhu Banner, XinBarag Right Banner and XinBarag Left Banner), east of Suihua (Zhaodong, Hailun, Suiling, Qinggang, Qingan, Lanxi, and Wangkui), Zhaozhou and Zhaoyuan of Daqing, Yufu of Songyuan and Yushu of Changchun.

\subsubsection{Membership degree of economic connection}

According to above methods and data of Table A1 in the Appendix, economic connection degree (between cities in the economic zone of northeast China and Harbin) and total external economic connection intensity of Harbin can be obtained, as shown in Table A2 in the Appendix.

In this study, cities whose economic connection degree with Harbin has reached $85 \%$ of the total degree, are

\begin{tabular}{|c|c|c|c|}
\hline City & $\begin{array}{l}\text { Original score of } \\
\text { comprehensive } \\
\text { power }\end{array}$ & $\begin{array}{l}\text { New score of } \\
\text { comprehensive } \\
\text { power }\end{array}$ & Rank \\
\hline Shenyang & 7.829 & 10.000 & 1 \\
\hline Dalian & 6.431 & 8.802 & 2 \\
\hline Changchun & 6.243 & 8.640 & 3 \\
\hline Harbin & 5.566 & 8.059 & 4 \\
\hline Jilin & 1.214 & 4.326 & 5 \\
\hline Anshan & 0.816 & 3.985 & 6 \\
\hline Daqing & 0.769 & 3.945 & 7 \\
\hline Chifeng & 0.176 & 3.436 & 8 \\
\hline Yingkou & -0.011 & 3.276 & 9 \\
\hline Qiqihar & -0.013 & 3.275 & 10 \\
\hline Qinhuangdao & -0.100 & 3.200 & 11 \\
\hline Jinhzhou & -0.314 & 3.016 & 12 \\
\hline Fushun & -0.315 & 3.015 & 13 \\
\hline Tongliao & -0.358 & 2.978 & 14 \\
\hline HulunBuir & -0.483 & 2.871 & 15 \\
\hline Liaoyang & -0.494 & 2.861 & 16 \\
\hline Benxi & -0.527 & 2.833 & 17 \\
\hline Songyuan & -0.553 & 2.811 & 18 \\
\hline Tonghua & -0.569 & 2.797 & 19 \\
\hline Huludao & -0.603 & 2.768 & 20 \\
\hline Siping & -0.705 & 2.680 & 21 \\
\hline Mudanjiang & -0.713 & 2.674 & 22 \\
\hline Dandong & -0.772 & 2.623 & 23 \\
\hline Chaoyang & -0.803 & 2.596 & 24 \\
\hline Suihua & -0.960 & 2.462 & 25 \\
\hline Panjin & -0.997 & 2.430 & 26 \\
\hline Liaoyuan & -1.079 & 2.360 & 27 \\
\hline Tieling & -1.096 & 2.345 & 28 \\
\hline Baishan & -1.162 & 2.289 & 29 \\
\hline Baicheng & -1.212 & 2.245 & 30 \\
\hline Fixin & -1.229 & 2.231 & 31 \\
\hline Jiamusi & -1.234 & 2.227 & 32 \\
\hline Qitaihe & -1.550 & 1.956 & 33 \\
\hline Shuangyashan & -1.805 & 1.737 & 34 \\
\hline Jixi & -1.868 & 1.683 & 35 \\
\hline Hegang & -2.276 & 1.333 & 36 \\
\hline Yichun & -2.578 & 1.074 & 37 \\
\hline Heihe & -2.664 & 1.000 & 38 \\
\hline
\end{tabular}

Table 3. The comprehensive power ranking of cities in northeast economic zone

included in attraction areas. From the Table A2 in the Appendix, 18 cities are included in the attraction area of Harbin. We can see in Figure 3, they are Suihua, Daqing, Songyuan, Changchun, Jilin, Mudanjiang, Qiqihar, Baicheng, Jiamusi, Fushun, Siping, Liaoyuan, Yichun, Shenyang, Qitaihe, Shuangyashan, Jixi and Hegang. 


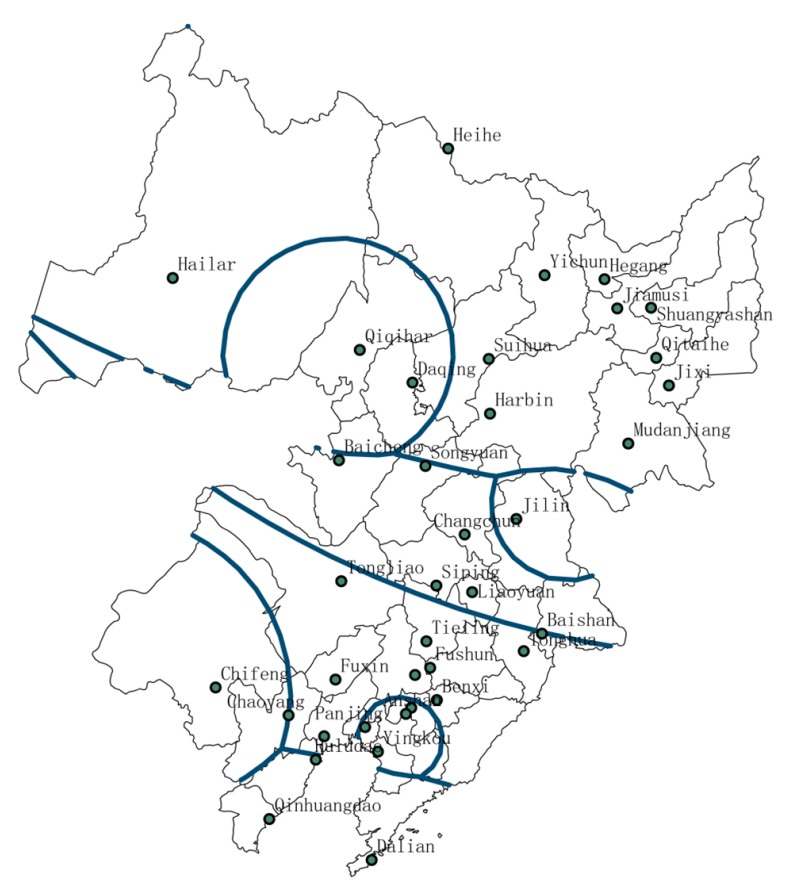

Figure 2. Attraction area division based on weighted-Voronoi-diagram and break-point model

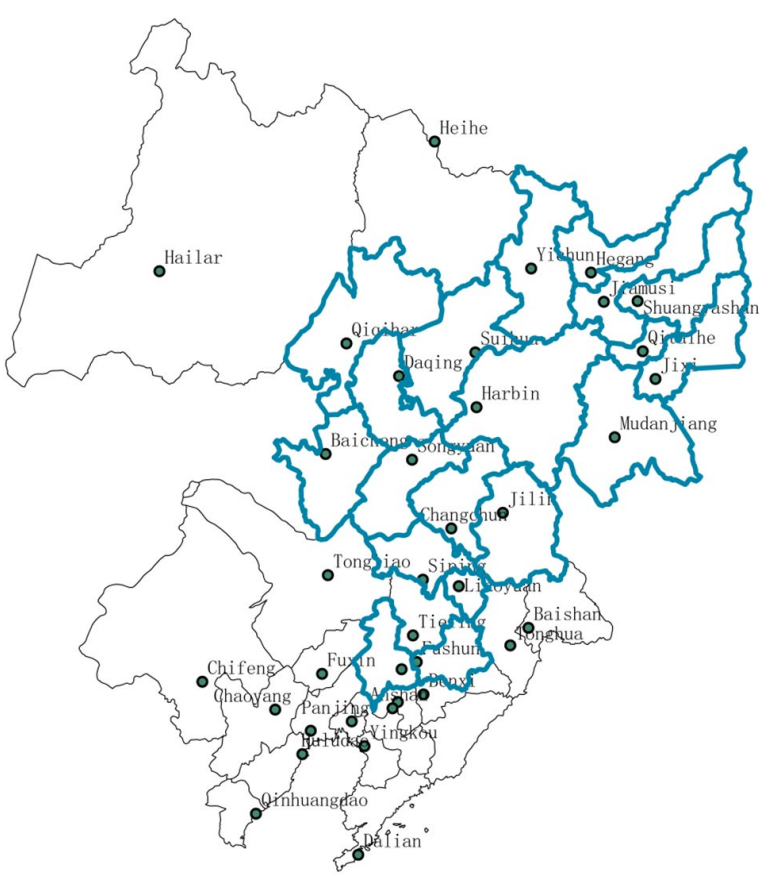

Figure 3. Attraction area division based on gravity model

\subsubsection{The optimal attraction area}

Combining break-point model and gravity model, we take the intersection area of calculation results of two models and finally get the key attraction area of Harbin railway container terminal. It contains Yichun, Hegang, Jiamusi, Shuangyashan, Qitaihe, Jixi, Mudanjiang, east area of Suihua city (Zhaodong, Hailun, Suiling, Qinggang, Qingan, Lanxi, and Wangkui), Zhaozhou and Zhaoyuan of Daqing, Yufu of Songyuan and Yushu of Changchun. The result is showed in Figure 4.

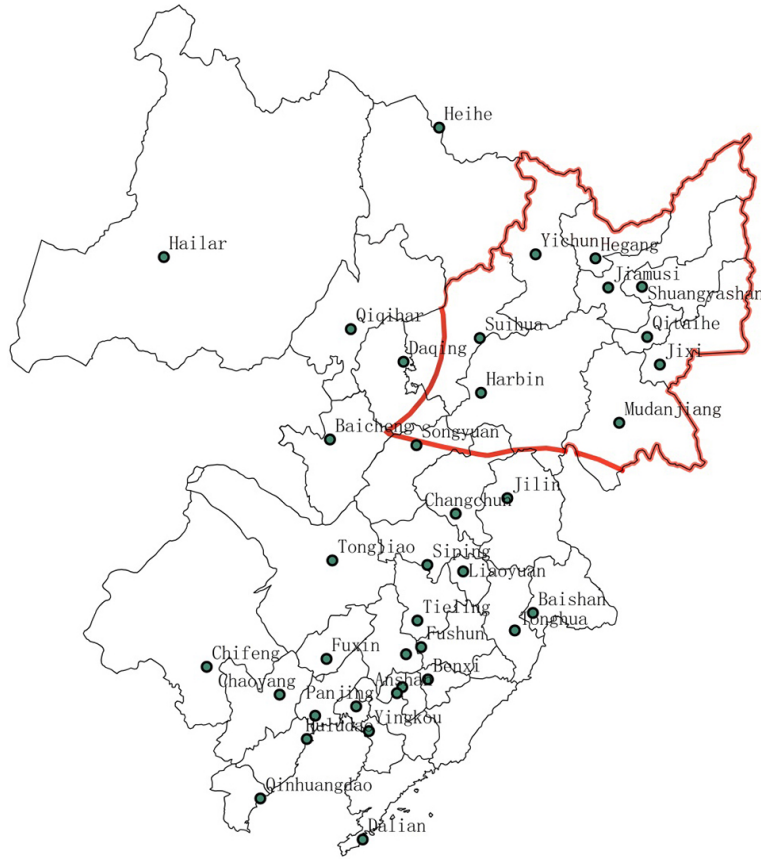

Figure 4. Attraction area of HRCCS

\subsection{Data collection for freight organization}

\subsubsection{Freight volume forecast}

Based on the gravity model, we figure out the attraction ratio of Harbin railway container terminal to the freight volume of each region in the attraction zone. Combining with the growth rate method, we firstly predict their freight volume, which will be transported to HRCCS in 2020. Then we calculate the proportion of Harbin - Europe Railway Express freight volume to total volume of HRCCS in 2020 (Table 4). At last, product of the two indicators is the freight volume transported to HRCCS on Harbin - Europe Railway Express from each city in the attraction area in 2020. Due to some data collection problems, the proportion of freight volume in several counties is determined by their share of the whole city's GDP.

\subsubsection{Transportation costs}

According to the Heilongjiang Automobile Freight Rate Rule issued by the Department of Transportation of Heilongjiang Province (DTHP 2020), Railway Freight Rate Rule of railway service and freight rate table (DTHP 2020), we set freight rate of railway as 0.16 yuan $/ \mathrm{t} \cdot \mathrm{km}$, and freight rate of highway as 0.4 yuan $/ \mathrm{t} \cdot \mathrm{km}$.

We assume that the transfer time and cost of each transfer station are the same, and each station meets the transport mode conversion requirements. The specific data is shown in Table 5.

\subsubsection{Transportation speed}

In this study, highway transport speed refers to the speed with the first level highway design standard, and railway transport speed refers to the speed of CR Express. In regards of time window restriction and current freight situ- 
Table 4. The volume of freight transported to Harbin container center station on Harbin - Europe Railway Express in 2020

\begin{tabular}{|c|c|c|}
\hline \multicolumn{2}{|r|}{ City } & $\begin{array}{l}\text { Freight volume on Harbin - } \\
\text { Europe Railway Express [t] }\end{array}$ \\
\hline \multicolumn{2}{|l|}{ Yichun } & 317.48 \\
\hline \multicolumn{2}{|l|}{ Hegang } & 445.74 \\
\hline \multicolumn{2}{|l|}{ Jiamusi } & 1937.71 \\
\hline \multicolumn{2}{|c|}{ Shuangyashan } & 364.42 \\
\hline \multicolumn{2}{|l|}{ Qitaihe } & 384.75 \\
\hline \multicolumn{2}{|l|}{ Jixi } & 1112.73 \\
\hline \multicolumn{2}{|c|}{ Mudanjiang } & 1732.41 \\
\hline \multirow{7}{*}{ Suihua } & Zhaodong & 1014.20 \\
\hline & hailun & 302.68 \\
\hline & Suiling county & 189.91 \\
\hline & Qinggang county & 141.30 \\
\hline & Qingan county & 215.29 \\
\hline & Lanxi county & 144.69 \\
\hline & Wangkui county & 179.51 \\
\hline \multirow{2}{*}{ Daqing } & Zhaozhou county & 136.06 \\
\hline & Zhaoyuan county & 43.04 \\
\hline Songyuan & Fuyu & 458.06 \\
\hline Changchun & Yushu & 198.25 \\
\hline
\end{tabular}

Table 5. Average transfer costs and time of different transportation modes

\begin{tabular}{|l|c|c|}
\hline \multicolumn{1}{|c|}{ Cost (time) $[$ yuan/h] } & Highway & Railway \\
\hline Highway & 0 & $50(1)$ \\
\hline Railway & $50(1)$ & 0 \\
\hline
\end{tabular}

ations, highway transport speed ranges of $60 \ldots 100 \mathrm{~km} / \mathrm{h}$, while railway transport speed ranges of $80 \ldots 120 \mathrm{~km} / \mathrm{h}$. Therefore, we take the highway transport speed as $60 \mathrm{~km} / \mathrm{h}$, railway transport as $100 \ldots 80 \mathrm{~km} / \mathrm{h}$ respectively for calculation.

\subsection{Calculation and analysis}

In this example, we take the average daily freight volume shown in Table A4 in the Appendix as freight volume of each city in attraction area, and hard time window for transport is set as $[0.5,8]$. According to freight organization optimization model in Section 3, we use LINGO (https://www.lindo.com/index.php/products/lingoand-optimization-modeling) to work out the results. The logistics organization scheme is shown in Tables 6-8. Calculation results based on highway transport speed at $60 \mathrm{~km} / \mathrm{h}$ and railway transport speed at $100 \mathrm{~km} / \mathrm{h}$ are shown in Table 6. Moreover, calculation results of highway transport speed at $60 \mathrm{~km} / \mathrm{h}$ and railway transport speed at $80 \mathrm{~km} / \mathrm{h}$ are shown in Table 7.
Table 6. Transportation modes and costs of railway container terminal of every city in attraction area

\begin{tabular}{|c|c|c|c|}
\hline \multicolumn{2}{|r|}{ City } & $\begin{array}{l}\text { Transporta- } \\
\text { tion mode }\end{array}$ & $\begin{array}{c}\text { Transportation } \\
\text { cost [yuan] }\end{array}$ \\
\hline \multicolumn{2}{|l|}{ Yichun } & \begin{tabular}{|l|} 
railway \\
\end{tabular} & 39138.93 \\
\hline \multicolumn{2}{|l|}{ Hegang } & railway & 63509.04 \\
\hline \multicolumn{2}{|c|}{ Jiamusi } & railway & 255002.60 \\
\hline \multicolumn{2}{|c|}{ Shaungyashan } & railway & 52389.02 \\
\hline \multicolumn{2}{|l|}{ Qitaihe } & railway & 55373.22 \\
\hline \multicolumn{2}{|l|}{ Jixi } & railway & 153378.70 \\
\hline \multicolumn{2}{|c|}{ Mudanjiang } & railway & 185021.40 \\
\hline \multirow{7}{*}{ Suihua } & Zhaodong & railway & 60933.14 \\
\hline & Hailun & railway & 26127.34 \\
\hline & Suiling county & railway & 15207.99 \\
\hline & Qinggang county & highway & 6861.53 \\
\hline & Qingan county & railway & 16930.41 \\
\hline & Lanxi county & highway & 3981.87 \\
\hline & Wangkui county & highway & 12515.44 \\
\hline \multirow{2}{*}{ Daqing } & Zhaozhou county & highway & 3379.73 \\
\hline & Zhaoyuan county & highway & 3592.98 \\
\hline Songyuan & Fuyu & railway & 30378.54 \\
\hline Changchun & Yushu & railway & 18794.10 \\
\hline
\end{tabular}

Table 7. Transport modes and costs of railway container terminal of each city in attraction area

\begin{tabular}{|c|c|c|c|}
\hline \multicolumn{2}{|c|}{ City } & $\begin{array}{l}\text { Transport } \\
\text { mode }\end{array}$ & $\begin{array}{l}\text { Transport cost } \\
\text { [yuan] }\end{array}$ \\
\hline \multicolumn{2}{|l|}{ Yichun } & railway & 39138.93 \\
\hline \multicolumn{2}{|l|}{ Hegang } & highway & 79377.38 \\
\hline \multicolumn{2}{|l|}{ Jiamusi } & railway & 255002.60 \\
\hline \multicolumn{2}{|c|}{ Shaungyashan } & highway & 66120.36 \\
\hline \multicolumn{2}{|l|}{ Qitaihe } & highway & 65930.76 \\
\hline \multicolumn{2}{|l|}{ Jixi } & railway & 153378.70 \\
\hline \multicolumn{2}{|l|}{ Mudanjiang } & railway & 185021.40 \\
\hline \multirow{7}{*}{ Suihua } & Zhaodong & highway & 25192.73 \\
\hline & Hailun & highway & 25267.73 \\
\hline & Suiling county & highway & 14942.12 \\
\hline & $\begin{array}{l}\text { Qinggang } \\
\text { county }\end{array}$ & highway & 6861.53 \\
\hline & Qingan county & highway & 14045.52 \\
\hline & Lanxi county & highway & 3981.87 \\
\hline & Wangkui county & highway & 12515.44 \\
\hline \multirow{2}{*}{ Daqing } & $\begin{array}{l}\text { Zhaozhou } \\
\text { county }\end{array}$ & highway & 3379.73 \\
\hline & $\begin{array}{l}\text { Zhaoyuan } \\
\text { county }\end{array}$ & highway & 3592.98 \\
\hline Songyuan & Fuyu & railway & 30378.54 \\
\hline changchun & Yushu & highway & 9627.02 \\
\hline
\end{tabular}


Table 8. Freight turnover and proportion at different speed

\begin{tabular}{|c|c|c|c|c|c|c|c|c|c|}
\hline \multicolumn{5}{|c|}{ Highway speed $60 \mathrm{~km} / \mathrm{h}$, railway speed $100 \mathrm{~km} / \mathrm{h}$} & \multicolumn{5}{|c|}{ Highway speed $60 \mathrm{~km} / \mathrm{h}$, railway speed $80 \mathrm{~km} / \mathrm{h}$} \\
\hline \multicolumn{2}{|c|}{ City } & $\begin{array}{l}\text { Transportation } \\
\text { mode }\end{array}$ & $\begin{array}{r}\text { Freight tu } \\
{[\mathrm{t} \cdot \mathrm{kn}}\end{array}$ & hover & \multicolumn{2}{|c|}{ City } & $\begin{array}{l}\text { Transportation } \\
\text { mode }\end{array}$ & \multicolumn{2}{|c|}{$\begin{array}{c}\text { Freight turnover } \\
{[\mathrm{t} \cdot \mathrm{km}]}\end{array}$} \\
\hline \multicolumn{2}{|l|}{ Yichun } & railway & 14540 & & \multicolumn{2}{|l|}{ Yichun } & railway & \multicolumn{2}{|c|}{145405.8} \\
\hline \multicolumn{2}{|l|}{ Hegang } & railway & 25763 & & \multicolumn{2}{|l|}{ Hegang } & highway & \multicolumn{2}{|c|}{198443.4} \\
\hline \multicolumn{2}{|c|}{ Jiamusi } & railway & 98823 & & \multicolumn{2}{|c|}{ Jiamusi } & railway & \multicolumn{2}{|c|}{988232.1} \\
\hline \multicolumn{2}{|c|}{ Shaungyashan } & railway & 21355 & & \multicolumn{2}{|c|}{ Shaungyashan } & highway & \multicolumn{2}{|c|}{165300.9} \\
\hline \multicolumn{2}{|c|}{ Qitaihe } & railway & 22584 & & \multicolumn{2}{|c|}{ Qitaihe } & highway & \multicolumn{2}{|c|}{164826.9} \\
\hline \multicolumn{2}{|l|}{ Jixi } & railway & 61088 & & \multicolumn{2}{|l|}{ Jixi } & railway & \multicolumn{2}{|c|}{610888.8} \\
\hline \multicolumn{2}{|l|}{ Mudanjiang } & railway & 61500 & & \multicolumn{2}{|l|}{ Mudanjiang } & railway & \multicolumn{2}{|c|}{615005.6} \\
\hline \multirow{7}{*}{ Suihua } & Zhaodong & railway & 6389 & & \multirow{7}{*}{ Suihua } & Zhaodong & highway & \multicolumn{2}{|c|}{62981.82} \\
\hline & Hailun & railway & 68708 & & & Hailun & highway & \multicolumn{2}{|c|}{63169.32} \\
\hline & $\begin{array}{l}\text { Suiling } \\
\text { county }\end{array}$ & railway & 35703 & & & $\begin{array}{l}\text { Suiling } \\
\text { county }\end{array}$ & highway & \multicolumn{2}{|c|}{37355.3} \\
\hline & $\begin{array}{l}\text { Qinggang } \\
\text { county }\end{array}$ & highway & 17153 & & & $\begin{array}{l}\text { Qinggang } \\
\text { county }\end{array}$ & highway & \multicolumn{2}{|c|}{17153.82} \\
\hline & $\begin{array}{l}\text { Qingan } \\
\text { county }\end{array}$ & railway & 3511 & & & $\begin{array}{l}\text { Qingan } \\
\text { county }\end{array}$ & highway & \multicolumn{2}{|c|}{35113.8} \\
\hline & $\begin{array}{l}\text { Lanxi } \\
\text { county }\end{array}$ & highway & 9954. & & & $\begin{array}{l}\text { Lanxi } \\
\text { county }\end{array}$ & highway & 9954 & 672 \\
\hline & $\begin{array}{l}\text { Wangkui } \\
\text { county }\end{array}$ & highway & 31288 & & & $\begin{array}{l}\text { Wangkui } \\
\text { county }\end{array}$ & highway & 3128 & 8.59 \\
\hline & $\begin{array}{l}\text { Zhaozhou } \\
\text { county }\end{array}$ & highway & 8449.3 & & & $\begin{array}{l}\text { Zhaozhou } \\
\text { county }\end{array}$ & highway & 8449 & 326 \\
\hline Daqing & $\begin{array}{l}\text { Zhaoyuan } \\
\text { county }\end{array}$ & highway & 8982. & & Daqing & $\begin{array}{l}\text { Zhaoyuan } \\
\text { county }\end{array}$ & highway & 8982 & 448 \\
\hline Songyuan & Fuyu & railway & 46722 & & Songyuan & Fuyu & railway & 4672 & 2.12 \\
\hline Changchun & Yushu & railway & 5551 & & Changchun & Yushu & highway & 2406 & 7.55 \\
\hline Railway turn & ver and pro & ortion & 3327107 & $97 \%$ & Railway turn & over and pro & ortion & 2406254 & $74.42 \%$ \\
\hline Highway tur & over and pr & portion & 110942.7 & $3 \%$ & Highway tur & lover and pr & portion & 827088 & $25.58 \%$ \\
\hline Total freight & urnover & & 34380 & & Total freight & turnover & & 3233 & 342 \\
\hline
\end{tabular}

It can be seen from Table 6 that railway is the transportation mode of cities where transport distance is above $300 \mathrm{~km}$, such as Yichun, Hegang and Jiamusi, while cities where transport distance is below $200 \mathrm{~km}$, such as Hailun and Suiling, choose transport mode mainly depending on the freight volume. Although transport distance of Zhaodong (in Suihua) is relatively short, freight volume is relatively in large scale, so it chooses railway. As for Zhaoyuan (in Daqing), transport distance is short, but its freight volume is small, so the transport mode is highway.

From Table 7, it can be seen that proportion of railway transportation decreases, which indicates that increase of railway speed has an obvious effect on the share of railway freight in freight market.

According to freight volume shown in Table 4 and highway and railway distance from each city in the attraction area to Harbin shown in Table A3 in Appendix, we can easily figure out freight turnover at different speeds of railway freight, as it's shown in Table 8. Moreover, comparison of freight turnover between railway and highway under different transport speed is shown in Figure 5.

When railway transportation speed is $80 \mathrm{~km} / \mathrm{h}$, the number of cities that transport freight by railway is 5 , ac- counting for $28 \%$, and freight turnover is 2406254 tons, accounting for $74.42 \%$ of total freight turnover.

When railway transportation speed is $100 \mathrm{~km} / \mathrm{h}$, the number of cities that transport freight by railway is 13 , accounting for $72 \%$, and freight turnover is 3327107 tons, accounting for $97 \%$ of total freight turnover.

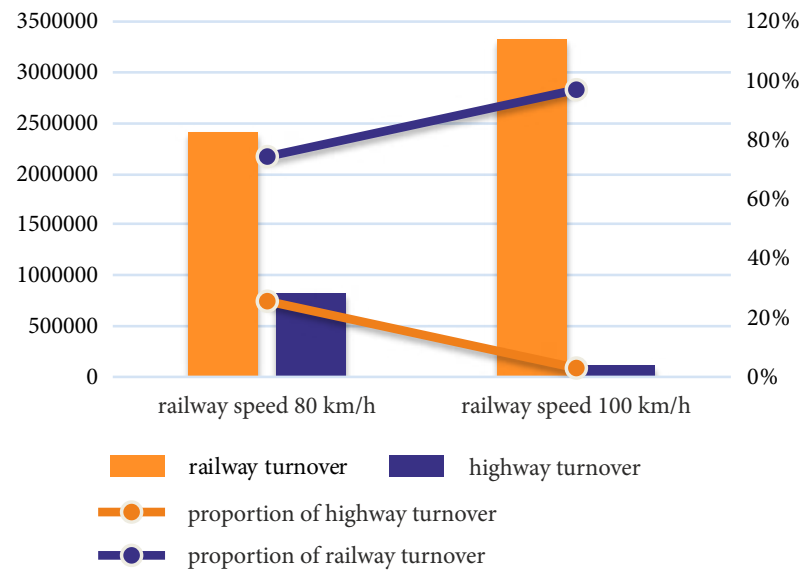

Figure 5. Comparison chart of freight turnover between railway and highway under different transport speed 
It can be seen that highway transport still dominates the market of short distance and less volume transport, while in long distance and larger volume transport, total transport cost of railway is still less than that of highway. From perspective of freight volume, railway undertakes more freight volume than highway transportation. Meanwhile, through comparative analysis, it is found that speed is the key to affecting freight volume of railway transportation, which means that increasing the speed of railway transportation has a significant effect on enhancing railway freight volume. Therefore, it is necessary to further improve the construction of railway stations and other infrastructure, and increase the speed of freight trains. Government should also take measures to improve China's comprehensive transport system and promote the rational and rapid development of CR Express.

\section{Conclusions}

This paper aims at solving the problems of attraction zone division and logistics organization optimization for container terminal of land freight express. Firstly, based on the interaction between the carrier city and surrounding cities, gravity model, break-point model and weightedVoronoi-diagram were used to determine the attraction area and attraction proportion of the carrier city. Secondly, on the basis of final attraction area divided by the railway container terminal, considering the limitation of hard time window and limited transportation capacity, a 0-1 planning model was established to minimize the total transportation cost, and LINGO was used to figure out this model. Finally, the feasibility and effectiveness of the above method and model were verified by taking Harbin railway container terminal as an example.

According to the current situation analysis of CR Express and results of the attraction area division, due to the normal operation and future sustainable development of CR Express, government cannot break the boundary of attraction areas of stations by financial subsidies. In the process of freight organization, government should make policies that encourage consigner to choose railway transportation from management aspect. In addition, government should gradually abandon relevant subsidy policies and rationalize station attraction areas on CR Express, so as to reduce the waste of transport resources and stabilize the transport market of CR Express.

On the basis of analysis results of attraction area division and freight organization optimization, feeder transportation service should choose reasonable transportation mode within attraction area, taking full advantages of various transportation modes, reducing cost and improving transportation efficiency.

In freight organization optimization, comparative analysis shows that influence of railway speed is the main factor of determining the proportion of railway transport in freight market, and improvement of railway speed has obvious effect on increasing freight volume of railway transportation. Therefore, in the freight organization process on CR Express, improvement of feeder transportation speed is an effective means to improve freight volume, increase railway revenue and realize sustainable development of CR Express.
However, method of this study still has some limitations. We only divide attraction area from macro perspective, without considering the influence of specific layout on the station and operation scheme. When we construct the freight organization optimization model, dynamic uncertainties such as weather and road conditions are not taken into account. In addition, it is necessary to carry out in-depth research.

\section{Acknowledgements}

This work was supported by the key project of science and technology development of China Railway Corporation (Grant No 2017X009-J), National Science Foundation of China (Grant No 71603162) and Science Foundation of Shanghai (Grant No 15ZR1420400).

\section{Appendix}

Table A1. The mileage between Harbin and other cities in the northeast economic zone

\begin{tabular}{|c|c|c|}
\hline No & City & Distance $[\mathrm{km}]$ \\
\hline 1 & Shenyang & 561.1 \\
\hline 2 & Dalian & 946.4 \\
\hline 3 & Changchun & 271.7 \\
\hline 4 & Jilin & 355.9 \\
\hline 5 & Anshan & 670.1 \\
\hline 6 & Daqing & 153.3 \\
\hline 7 & Chifeng & 861.1 \\
\hline 8 & Yingkou & 748.3 \\
\hline 9 & Qiqihar & 308.3 \\
\hline 10 & Qinhuangdao & 961.9 \\
\hline 11 & Jinzhou & 780.7 \\
\hline 12 & Fushun & 586.8 \\
\hline 13 & Tongliao & 522.3 \\
\hline 14 & Hulunbuir & 751.9 \\
\hline 15 & Liaoyang & 642.9 \\
\hline 16 & Benxi & 606 \\
\hline 17 & Songyuan & 196.7 \\
\hline 18 & Tonghua & 539.8 \\
\hline 19 & Huludao & 826.8 \\
\hline 20 & Siping & 389.5 \\
\hline 21 & Mudanjiang & 335.4 \\
\hline 22 & Dandong & 811.2 \\
\hline 23 & Chaoyang & 772.7 \\
\hline 24 & Huihua & 112.5 \\
\hline 25 & \begin{tabular}{|l|} 
Panjin \\
\end{tabular} & 724.4 \\
\hline 26 & Liaoyuan & 389.8 \\
\hline 27 & Tieling & 506.1 \\
\hline 28 & Baishan & 571.6 \\
\hline 29 & Baicheng & 398.1 \\
\hline 30 & Fuxin & 649.1 \\
\hline 31 & Jiamusi & 381 \\
\hline 32 & Qitaihe & 428.4 \\
\hline 33 & Shaungyashan & 453.6 \\
\hline 34 & Jixi & 478.4 \\
\hline 35 & Hegang & 445.2 \\
\hline 36 & Yichun & 323 \\
\hline 37 & Heihe & 495 \\
\hline
\end{tabular}

Note: data source - China Railway Harbin Group Co., Ltd. (CR 2019). 
Table A2. Economic connection intensity between Harbin and other cities and cumulative percentage

\begin{tabular}{|c|c|c|c|c|c|c|c|}
\hline No & City & $\begin{array}{c}\text { Economic } \\
\text { connection intensity } \\
F_{1 k} \\
\end{array}$ & $\begin{array}{l}\text { Cumulative } \\
\text { percentage [\%] }\end{array}$ & No & City & $\begin{array}{c}\text { Economic } \\
\text { connection intensity } \\
F_{1 k} \\
\end{array}$ & $\begin{array}{l}\text { Cumulative } \\
\text { percentage }[\%]\end{array}$ \\
\hline 1 & Suihua & 432.36 & 21.72 & 20 & Baishan & 23.34 & 89.05 \\
\hline 2 & Daqing & 282.41 & 35.90 & 21 & Tonghua & 22.95 & 90.20 \\
\hline 3 & Songyuan & 195.57 & 45.72 & 22 & Tieling & 21.44 & 91.28 \\
\hline 4 & Changchun & 142.25 & 52.87 & 23 & Benxi & 17.19 & 92.14 \\
\hline 5 & Jilin & 130.39 & 59.42 & 24 & Anshan & 15.90 & 92.94 \\
\hline 6 & Mudanjiang & 64.49 & 62.66 & 25 & Liaoyang & 14.87 & 93.69 \\
\hline 7 & Qiqihar & 63.02 & 65.82 & 26 & Fuxin & 12.89 & 94.33 \\
\hline 8 & Baichng & 46.79 & 68.17 & 27 & HulunBuir & 11.91 & 94.93 \\
\hline 9 & Jiamusi & 44.54 & 70.41 & 28 & Heihe & 11.59 & 95.51 \\
\hline 10 & Fushun & 41.24 & 72.48 & 29 & Yingkou & 11.49 & 96.09 \\
\hline 11 & Siping & 40.59 & 74.52 & 30 & Dalian & 11.09 & 96.65 \\
\hline 12 & Liaoyuan & 38.11 & 76.43 & 31 & Panjin & 10.88 & 97.20 \\
\hline 13 & Yichun & 37.43 & 78.31 & 32 & Jinzhou & 10.44 & 97.72 \\
\hline 13 & Yichun & 37.43 & 78.31 & 33 & Dandong & 10.34 & 98.24 \\
\hline 14 & Shenyang & & 80.13 & 34 & Chaoyang & 9.79 & 98.73 \\
\hline 15 & Qitaihe & 34.03 & 81.84 & 35 & Chifeng & 9.63 & 99.21 \\
\hline 16 & Shuangyashan & 31.47 & 83.42 & 36 & Huludao & 8.76 & 99.65 \\
\hline 17 & Jixi & 31.01 & 84.98 & 37 & Qinhuangdao & 6.89 & 100.00 \\
\hline 18 & Hegang & 29.24 & 86.45 & \multirow{2}{*}{\multicolumn{4}{|c|}{$\begin{array}{l}\text { Total external economic connection intensity of Harbin } \\
F_{1}=1990.998285\end{array}$}} \\
\hline 19 & Tongliao & 28.40 & 87.88 & & & & \\
\hline
\end{tabular}

Table A3. The railway and highway distance from each city in attraction area to Harbin $[\mathrm{km}]$

\begin{tabular}{|c|c|c|c|c|c|c|c|}
\hline Mode of transportation & Yichun & Hegang & Jiamusi & Shaungyashan & Qitaihe & Jixi & Mudanjiang \\
\hline Highway & 323 & 445.2 & 381 & 453.6 & 428.4 & 478.4 & 335.4 \\
\hline Railway & 458 & 578 & 510 & 586 & 587 & 549 & 355 \\
\hline City & \multicolumn{7}{|c|}{ Suihua } \\
\hline Mode of transportation & Zhaodong & Hailun & $\begin{array}{l}\text { Suiling } \\
\text { county }\end{array}$ & $\begin{array}{l}\text { Qinggang } \\
\text { county }\end{array}$ & $\begin{array}{l}\text { Qingan } \\
\text { county }\end{array}$ & $\begin{array}{l}\text { Lanxi } \\
\text { county }\end{array}$ & $\begin{array}{l}\text { Wangkui } \\
\text { county }\end{array}$ \\
\hline Highway & 62.1 & 208.7 & 196.7 & 121.4 & 163.1 & 68.8 & 174.3 \\
\hline Railway & 63 & 227 & 188 & - & 179 & - & - \\
\hline $\mathrm{X}^{2}$ & \multicolumn{2}{|c|}{ Daqing } & Songyuan & Changchun & - & - & 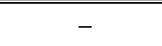 \\
\hline Mode of transportation & Zhaozhoucouty & $\begin{array}{c}\text { Zhaoyuan } \\
\text { county }\end{array}$ & Fuyu & Yushu & - & - & - \\
\hline Highway & 62.1 & 208.7 & 196.7 & 121.4 & - & - & - \\
\hline Railway & - & - & 102 & 280 & - & - & - \\
\hline
\end{tabular}

Note: “-” means no railway between the two cities. 
Table A4. Freight volume statistics of each city in attraction area to Harbin

\begin{tabular}{|c|c|c|c|c|c|}
\hline \multicolumn{2}{|c|}{ City } & $\begin{array}{l}\text { Annual freight volume } \\
\qquad\left[10^{4} \mathrm{t}\right]\end{array}$ & $\begin{array}{l}\text { Average daily freight volume } \\
\qquad\left[10^{4} \mathrm{t}\right]\end{array}$ & $\begin{array}{l}\text { Attraction } \\
\text { rate }[\%]\end{array}$ & $\begin{array}{l}\text { Average daily freight } \\
\text { volume to Harbin [t] }\end{array}$ \\
\hline \multicolumn{2}{|l|}{ Yichun } & 868 & 2.38 & 1.88 & 447.07 \\
\hline \multicolumn{2}{|l|}{ Hegang } & 1560 & 4.27 & 1.47 & 627.68 \\
\hline \multicolumn{2}{|l|}{ Jiamusi } & 4452 & 12.20 & 2.24 & 2728.61 \\
\hline \multicolumn{2}{|c|}{ Shaungyashan } & 1185 & 3.25 & 1.58 & 513.16 \\
\hline \multicolumn{2}{|c|}{ Qitaihe } & 1157 & 3.17 & 1.71 & 541.79 \\
\hline \multicolumn{2}{|l|}{ Jixi } & 3672 & 10.06 & 1.56 & 1566.90 \\
\hline \multicolumn{2}{|l|}{ Mudanjiang } & 2749 & 7.53 & 3.24 & 2439.51 \\
\hline \multirow{7}{*}{ Suihua } & Zhaodong & 240 & 0.66 & 21.72 & 1428.16 \\
\hline & Hailun & 72 & 0.20 & 21.72 & 426.22 \\
\hline & Suiling county & 45 & 0.12 & 21.72 & 267.42 \\
\hline & $\begin{array}{l}\text { Qinggang } \\
\text { county }\end{array}$ & 33 & 0.09 & 21.72 & 198.97 \\
\hline & Qingan county & 51 & 0.14 & 21.72 & 303.16 \\
\hline & Lanxi county & 34 & 0.09 & 21.72 & 203.75 \\
\hline & $\begin{array}{l}\text { Wangkui } \\
\text { county }\end{array}$ & 42 & 0.12 & 21.72 & 252.78 \\
\hline \multirow{2}{*}{ Daqing } & $\begin{array}{l}\text { Zhaozhou } \\
\text { county }\end{array}$ & 49 & 0.14 & 14.18 & 191.60 \\
\hline & $\begin{array}{l}\text { Zhaoyuan } \\
\text { county }\end{array}$ & 16 & 0.04 & 14.18 & 60.61 \\
\hline Songyuan & Fuyu & 240 & 0.66 & 9.82 & 645.02 \\
\hline Changchun & Yushu & 143 & 0.39 & 7.14 & 279.17 \\
\hline
\end{tabular}

Note: data source - China Statistical Yearbook 2016 (CSP 2016).

\section{References}

Abellanas, M.; Hurtado, F.; Sacristán, V.; Icking, C.; Ma, L.; Klein, R.; Palop, B. 2003. Voronoi Diagram for services neighboring a highway, Information Processing Letters 86(5): 283-288. https://doi.org/10.1016/s0020-0190(02)00505-7

Banomyong, R.; Beresford, A. K. C. 2001. Multimodal transport: the case of Laotian garment exporters, International Journal of Physical Distribution \& Logistics Management 31(9): 663685. https://doi.org/10.1108/09600030110408161

Bhattacharya, A.; Kumar, S. A.; Tiwari, M. K.; Talluri, S. 2014. An intermodal freight transport system for optimal supply chain logistics, Transportation Research Part C: Emerging Technologies 38: 73-84. https://doi.org/10.1016/j.trc.2013.10.012

Bierwirth, C.; Kirschstein, T.; Meisel, F. 2012. On transport service selection in intermodal rail/road distribution networks, Business Research 5(2): 198-219.

https://doi.org/10.1007/bf03342738

Borndörfer, R.; Klug, T.; Schlechte, T.; Fügenschuh, A.; Schang, T.; Schülldorf, H. 2016. The freight train routing problem for congested railway networks with mixed traffic, Transportation Science 50(2): 408-423. https://doi.org/10.1287/trsc.2015.0656

Boukebbab, S.; Boulahlib, M. S. 2015. The spatial interactions using the gravity model: application at the evaluation of transport efficiency at Constantine city, Algeria, Advances in Intelligent Systems and Computing 365: 35-44. https://doi.org/10.1007/978-3-319-19216-1_4

Bowen, J. T. 2012. A spatial analysis of FedEx and UPS: hubs, spokes, and network structure, Journal of Transport Geography 24: 419-431. https://doi.org/10.1016/j.jtrangeo.2012.04.017
Butko, T.; Prokhorov, V.; Kalashnikova, T.; Riabushka, Y. 2019. Organization of railway freight short-haul transportation on the basis of logistic approaches, Procedia Computer Science 149: 102-109. https://doi.org/10.1016/j.procs.2019.01.113

Chang, T.-S. 2008. Best routes selection in international intermodal networks, Computers \& Operations Research 35(9): 2877-2891. https://doi.org/10.1016/j.cor.2006.12.025

Cho, J. H.; Kim, H. S.; Choi, H. R. 2012. An intermodal transport network planning algorithm using dynamic programming - a case study: from Busan to Rotterdam in intermodal freight routing, Applied Intelligence 36(3): 529-541. https://doi.org/10.1007/s10489-010-0223-6

Choong, S. T.; Cole, M. H.; Kutanoglu, E. 2002. Empty container management for intermodal transportation networks, Transportation Research Part E: Logistics and Transportation Review 38(6): 423-438:

https://doi.org/10.1016/S1366-5545(02)00018-2

Corry, P.; Kozan, E. 2006. An assignment model for dynamic load planning of intermodal trains, Computers \& Operations Research 33(1): 1-17. https://doi.org/10.1016/j.cor.2004.05.013

CR. 2019. China Railway Harbin Group Co., Ltd. Available from Internet: http://www.china-railway.com.cn

CSP. 2016. China Statistical Yearbook 2016. China Statistics Press (CSP). Available from Internet: http://www.stats.gov.cn/tjsj/ndsj/2016/indexeh.htm

Demir, E.; Burgholzer, W.; Hrušovský, M.; Arıkan, E.; Jammernegg, W.; Woensel, T. V. 2016. A green intermodal service network design problem with travel time uncertainty, Transportation Research Part B: Methodological 93: 789-807. https://doi.org/10.1016/j.trb.2015.09.007 
DTHP. 2020. Department of Transportation of Heilongjiang Province (DTHP), China. Available from Internet: http://jt.hlj.gov.cn (in Chinese).

El-Geneidy, A.; Grimsrud, M.; Wasfi, R.; Tétreault, P.; Surprenant-Legault, J. 2014. New evidence on walking distances to transit stops: identifying redundancies and gaps using variable service areas, Transportation 41(1): 193-210. https://doi.org/10.1007/s11116-013-9508-z

Feng, X.; He, S.-W.; Li, Y.-B. 2019. Temporal characteristics and reliability analysis of railway transportation networks, Transportmetrica A: Transport Science 15(2): 1825-1847. https://doi.org/10.1080/23249935.2019.1647308

Galvão, L. C.; Novaes, A. G. N.; De Cursi, J. E. S.; Souza, J. C. 2006. A multiplicatively-weighted Voronoi diagram approach to logistics districting, Computers \& Operations Research 33(1): 93-114. https://doi.org/10.1016/j.cor.2004.07.001

Hao, C.; Yue, Y. 2016. Optimization on combination of transport routes and modes on dynamic programming for a container multimodal transport system, Procedia Engineering 137: 382390. https://doi.org/10.1016/j.proeng.2016.01.272

Hübner, A.; Ostermeier, M. 2018. A multi-compartment vehicle routing problem with loading and unloading costs, Transportation Science 53(1): 282-300.

https://doi.org/10.1287/trsc.2017.0775

Jiang, B.; Li, J.; Mao, X. 2012. Container ports multimodal transport in china from the view of low carbon, The Asian Journal of Shipping and Logistics 28(3): 321-343.

https://doi.org/10.1016/j.ajsl.2013.01.003

Jiang, C.; Zhang, A. 2016. Airline network choice and market coverage under high-speed rail competition, Transportation Research Part A: Policy and Practice 92: 248-260. https://doi.org/10.1016/j.tra.2016.06.008

Kalinina, M.; Olsson, L.; Larsson, A. 2013. A multi objective chance constrained programming model for intermodal logistics with uncertain time, International Journal of Computer Science Issues 10(6): 35-44.

Kim, K. W.; Lee, D. W.; Chun, Y. H. 2010. A comparative study on the service coverages of subways and buses, KSCE Journal of Civil Engineering 14(6): 915-922. https://doi.org/10.1007/s12205-010-0987-6

Lawson, C. T.; Holguín-Veras, J.; Sánchez-Díaz, I.; Jaller, M.; Campbell, S.; Powers, E. L. 2012. Estimated generation of freight trips based on land use, Transportation Research Record: Journal of the Transportation Research Board 2269: 65-72. https://doi.org/10.3141/2269-08

Long, X.; Zhang, Y.; Chen, Y. 2011. Using Voronoi diagram in construction the scope of logistics park hinterland: an engineering application, Systems Engineering Procedia 2: 69-76. https://doi.org/10.1016/j.sepro.2011.10.009

Lozano, A.; Storchi, G. 2001. Shortest viable path algorithm in multimodal networks, Transportation Research Part A: Policy and Practice 35(3): 225-241.

https://doi.org/10.1016/S0965-8564(99)00056-7

Lu, B.; Huo, Y. 2013. Potential model for predicting logistics requirements based on regional economics, ICIC Express Letters: an International Journal of Research and Surveys 7(3): 717-721.

Moore, B. 1981. Principal component analysis in linear systems: controllability, observability, and model reduction, IEEE Transactions on Automatic Control 26(1): 17-32. https://doi.org/10.1109/TAC.1981.1102568

O'Sullivan, S.; Morrall, J. 1996. Walking distances to and from light-rail transit stations, Transportation Research Record: Journal of the Transportation Research Board 1538: 19-26. https://doi.org/10.3141/1538-03
Qu, L.; Chen, Y.; Mu, X. 2008. A transport mode selection method for multimodal transportation based on an adaptive ANN system, in 2008 Fourth International Conference on Natural Computation, 18-20 October 2008, Jinan, China, 436-440. https://doi.org/10.1109/ICNC.2008.165

Sánchez-Díaz, I.; Holguín-Veras, J.; Wang, X. 2016. An exploratory analysis of spatial effects on freight trip attraction, Transportation 43(1): 177-196. https://doi.org/10.1007/s11116-014-9570-1

Seo, Y. J.; Chen, F.; Roh, S. Y. 2017. Multimodal transportation: the case of laptop from Chongqing in China to Rotterdam in Europe, The Asian Journal of Shipping and Logistics 33(3): 155-165. https://doi.org/10.1016/j.ajsl.2017.09.005

Talley, W. K.; Ng, M. W. 2018. Hinterland transport chains: a behavioral examination approach, Transportation Research Part E: Logistics and Transportation Review 113: 94-98. https://doi.org/10.1016/j.tre.2018.03.001

Verma, M.; Verter, V. 2010. A lead-time based approach for planning rail-truck intermodal transportation of dangerous goods, European Journal of Operational Research 202(3): 696-706. https://doi.org/10.1016/j.ejor.2009.06.005

Verma, M.; Verter, V.; Zufferey, N. 2012. A bi-objective model for planning and managing rail-truck intermodal transportation of hazardous materials, Transportation Research Part E: Logistics and Transportation Review 48(1): 132-149.

https://doi.org/10.1016/j.tre.2011.06.001

Wang, Z.; Shi, P. 2017. Analyses of metro station service area in shanghai downtown based on traffic networks, Journal of the Indian Society of Remote Sensing 45(2): 337-352. https://doi.org/10.1007/s12524-016-0595-0

Wei, H.; Dong, M. 2019. Import-export freight organization and optimization in the dry-port-based cross-border logistics network under the belt and road initiative, Computers \& Industrial Engineering 130: 472-484.

https://doi.org/10.1016/j.cie.2019.03.007

Wei, W.; Xuejun, F.; Li, H. 2008. Research on regional logistics system layout optimization based on weighted Voronoi diagram and gravitational model, in 2008 IEEE International Conference on Automation and Logistics, 1-3 September 2008, Qingdao, China, 2078-2083.

https://doi.org/10.1109/ICAL.2008.4636506

Xia, W.; Jiang, C.; Wang, K.; Zhang, A. 2019. Air-rail revenue sharing in a multi-airport system: effects on traffic and social welfare, Transportation Research Part B: Methodological 121: 304-319. https://doi.org/10.1016/j.trb.2018.10.002

Yang, X.; Low, J. M. W.; Tang, L. C. 2011. Analysis of intermodal freight from China to Indian Ocean: A goal programming approach, Journal of Transport Geography 19(4): 515-527. https://doi.org/10.1016/j.jtrangeo.2010.05.007

Yao, X.-S.; Huang, H.-Z.; Zhou, Z.-R. 2002. Study on multi-objective optimization based on generalized satisfactory degree theory for transportation capability of railway-network, in International Conference on Traffic and Transportation Studies (ICTTS) 2002, 23-25 July 2002, Guilin, China, 947-952. https://doi.org/10.1061/40630(255)132

Yu, B.; Shu, S.; Liu, H.; Song, W.; Wu, J.; Wang, L.; Chen, Z. 2014. Object-based spatial cluster analysis of urban landscape pattern using nighttime light satellite images: a case study of China, International Journal of Geographical Information Science 28(11): 2328-2355. https://doi.org/10.1080/13658816.2014.922186

Zografos, K. G.; Androutsopoulos, K. N. 2008. Algorithms for itinerary planning in multimodal transportation networks, IEEE Transactions on Intelligent Transportation Systems 9(1): 175-184. https://doi.org/10.1109/TITS.2008.915650 